\title{
Entomocorus melaphareus, a new species of auchenipterid catfish (Osteichthyes: Siluriformes) from the lower and middle reaches of the rio Amazonas
}

\author{
Alberto Akama* and Carl J. Ferraris, Jr.**
}

\begin{abstract}
A new species of auchenipterid catfish, Entomocorus melaphareus, is described. The new species is readily distinguished from its two congeners, Entomocorus benjamini Eigenmann, 1917, and E. gameroi Mago Leccia, 1983, by having darkly pigmented, rather than hyaline, pectoral and pelvic fins. Entomocorus melaphareus is known from the margins of the lower and middle rio Amazonas, and is the only species of the genus known from the main channel of that river.

Uma nova espécie de bagre da família Auchenipteridae é aqui descrita com base em dois exemplares coletados recentemente no baixo e médio rio Amazonas. Entomocorus melaphareus se distingue das demais espécies do gênero pelo colorido escuro de suas nadadeiras peitoral e pélvica, contrastando com as nadadeiras hialinas de Entomocorus benjamini Eigenmann, 1917 e E. gameroi Mago Leccia, 1983. Esta é a única espécie do gênero Entomocorus conhecida na calha do rio Amazonas.
\end{abstract}

Key words: Auchenipteridae, Neotropical, Entomocorus benjamini, Entomocorus gameroi.

\section{Introduction}

Recent collections along the margin of the rio Amazonas in Brazil, between Belém and Manaus yielded two specimens of a catfish that clearly belonged to the auchenipterid genus Entomocorus Eigenmann, 1917. All previous records of Entomocorus were, instead, from the upper rio Paraguay system or upper rio Mamore/Guaporé system (Entomocorus benjamini Eigenmann, 1917) and the lower and middle rio Orinoco system (Entomocorus gameroi Mago Leccia, 1983; Royero, 1999). Upon close examination, the two specimens from the Amazon were found to differ from both of these species in color pattern, and clearly represent a previously unknown species, herein named Entomocorus melaphareus, that represents a marked increase in the distributional range of the genus.

\section{Material and Methods}

Fin-ray counts, taken under a stereomicroscope, include all elements and treat the two posteriormost dorsal- and anal-fin rays that articulate on the last distal radial as separate rays. Caudal-fin ray counts include branched rays and the longest unbranched ray of the dorsal and ventral lobes.

Measurements were taken with digital dial calipers and were point-to-point, as follows: body depth was taken at the dorsal-fin origin; head length (HL) was measured parallel to the body axis, from the snout tip to the posterior edge of the bony operculum; cleithral width was measured across the bony cleithrum just anterior to the pectoral spine; orbital diameter was taken as the horizontal measure across the middle of the eye bounded by the infraorbital bones; snout length is from the snout tip to the anterior margin of

\footnotetext{
* Museu de Zoologia da Universidade de São Paulo, Caixa Postal 42594, 04299-970 São Paulo, SP, Brazil. e-mail: aakama@ib.usp.br ** 2944 NE Couch St., Portland, Oregon, USA. e-mail: ferraris@msn.com
} 
the eye; bony interorbital distance represents the shortest distance across the bony interorbit; predorsal length was taken from anterior edge of the first dorsal fin spine (spinelet) to the snout tip; prepectoral length is the distance from the pectoral spine origin to the snout tip; pectoral-fin spine length is from the anterior (or lateral) spine base to the tip of the bony spine, not including the fleshy or flexible bony terminal portion of the spine; dorsal-spine length is measured from the junction point between the first spine (spinelet) and the second spine to the tip of the bony spine, not including the fleshy or flexible bony terminal parts; pelvic-fin length is the distance from the attachment of the first unbranched ray to the fin tip; adipose-fin height is taken at the highest point of the adipose fin to the body; length of anal-fin base is measured from the origin of the anal fin to the insertion of the last anal-fin ray; and caudalpeduncle length is measured from the insertion of the last anal-fin ray to the junction of hipurals 2 and 3 (Lundberg \& Baskin, 1969).

Proportional measurements are presented as percentages of standard length (SL) or head length (HL) as indicated. Institutional abbreviations used here are as follows: ANSP, Academy of Natural Sciences, Philadelphia; MZUSP, Museu de Zoologia, Universidade de São Paulo; USNM, National Museum of Natural History, Smithsonian Institution, Washington.

\section{Entomocorus melaphareus, new species}

Figs. 1-2

Holotype. MZUSP 76413, 58.6 mm SL, Brazil, Pará, Monte Alegre, Costa do Curuá, left bank of Amazon River, $2^{\circ} 13^{\prime} 46.2^{\prime \prime S} 54^{\circ} 01^{\prime} 27.6$ 'W. 7 Mar 2002. A. Akama, C. Lopes \& S. Fonteles Santos.

Paratype. MZUSP 76445, $43.1 \mathrm{~mm}$ SL, Brazil, Amazonas, between Parintins and Itacoatiara, Amazon River along left bank, at mouth of igarapé, 2'31'48.0"S 56 58'53.2”W. 13 Mar 2002. A. Akama, C. Lopes \& S. Fonteles Santos.

Diagnosis. A species of Entomocorus having pelvic and pectoral fins densely covered with dark pigment, at least along anterior rays, in contrast to the hyaline fins of its congeners.

Description. [Fin ray counts: D II,5; P I,8; V i,5; A iv,15 (paratype) or iv,17 (holotype); C i,7/8,i] Lateral, dorsal, and ventral views in Fig. 1 illustrate head and body shape, form and position of fins, and pigment pattern. Descriptive morphometric and meristic data presented in Table 1.

Body robust, short; body depth at dorsal-fin origin 24.1$25.9 \%$ of SL, at anal-fin origin $24.5-24.6 \%$ of SL; body compressed, width at anal-fin origin $32.2-38.4 \%$ body depth at that point. Lateral line complete and midlateral; canal forms irregular zig-zag pattern, with oblique, short, posteriorly directed branches, but canal does not bifurcate at caudal-fin base.

Head depressed anteriorly; depth at dorsal-fin origin slightly longer than width at cleithrum; profile straight from snout to dorsal-fin origin. Snout length slightly longer than orbital diameter, snout margin rounded. Interorbital width slightly less than one-half of HL (44.4-45.5\%) and almost equal to eye diameter (37.8-38.4\% of HL). Eye large, lateral, visible in both dorsal and ventral views. Barbels slender; maxillary barbel extending past anal-fin origin. Mandibular barbels originate in transverse row at lower jaw margin just lateral to jaw symphysis; inner mental barbel extends to pectoral-fin base; outer mental barbel reaches nearly to middle of pectoral fin. Branchiostegal membrane broadly attached to symphysis. Gill opening relatively wide, ventral margin of opening extends ventral to horizontal through pectoral-spine base. Mouth nearly terminal, upper jaw extends slightly beyond lower jaw. Teeth of upper jaw visible when mouth closed. Jaw teeth minute, barely extending through epidermal tissue; teeth in one row on upper jaw, with additional 1 or 2 rows laterally; tooth band on lower jaw with one row laterally and an irregular tooth patch at symphysis.

Dorsal-fin origin located posterior to vertical through opercular flap. Dorsal-fin base narrow, its length one-third of HL. Dorsal-fin spine slender, straight; anterior margin of spine smooth, posterior margin with medial row of widely spaced and reduced dentations. Dorsal fin with five branched rays; rays slender. Adipose dorsal fin relatively large and triangular.

Caudal fin deeply forked, lobes pointed. Outermost branched rays twice as long as middle rays. Lobes almost symmetrical, upper lobe slightly longer than lower lobe.

Anal-fin base short, its length approximately two times in HL; anal-fin origin located near to vertical through adipose-fin origin. Last unbranched and first branched analfin rays longest; rays decreasing slighthy in length posteriorly. Anal-fin margin straight in paratype, but convex in nuptial males (holotype; see Sexual dimorphism, below). Anal fin with 4 or 5 unbranched, and 15 to 17 branched, rays.

Pelvic fin acutely pointed, first branched ray longest. Pelvic-fin with 1 unbranched, and 5 branched, rays. Pelvic-fin origin located at approximately middle of SL.

Pectoral-fin with 1 stout spine and 8 branched rays. Spine serrated along both margins, antrorse serrae with 16-17 dentations on anterior margin and retrorse serrae with 13-15 dentations on posterior margin. Anterior pectoral-fin rays longest, fin margin straight laterally and convex along medial most rays. 


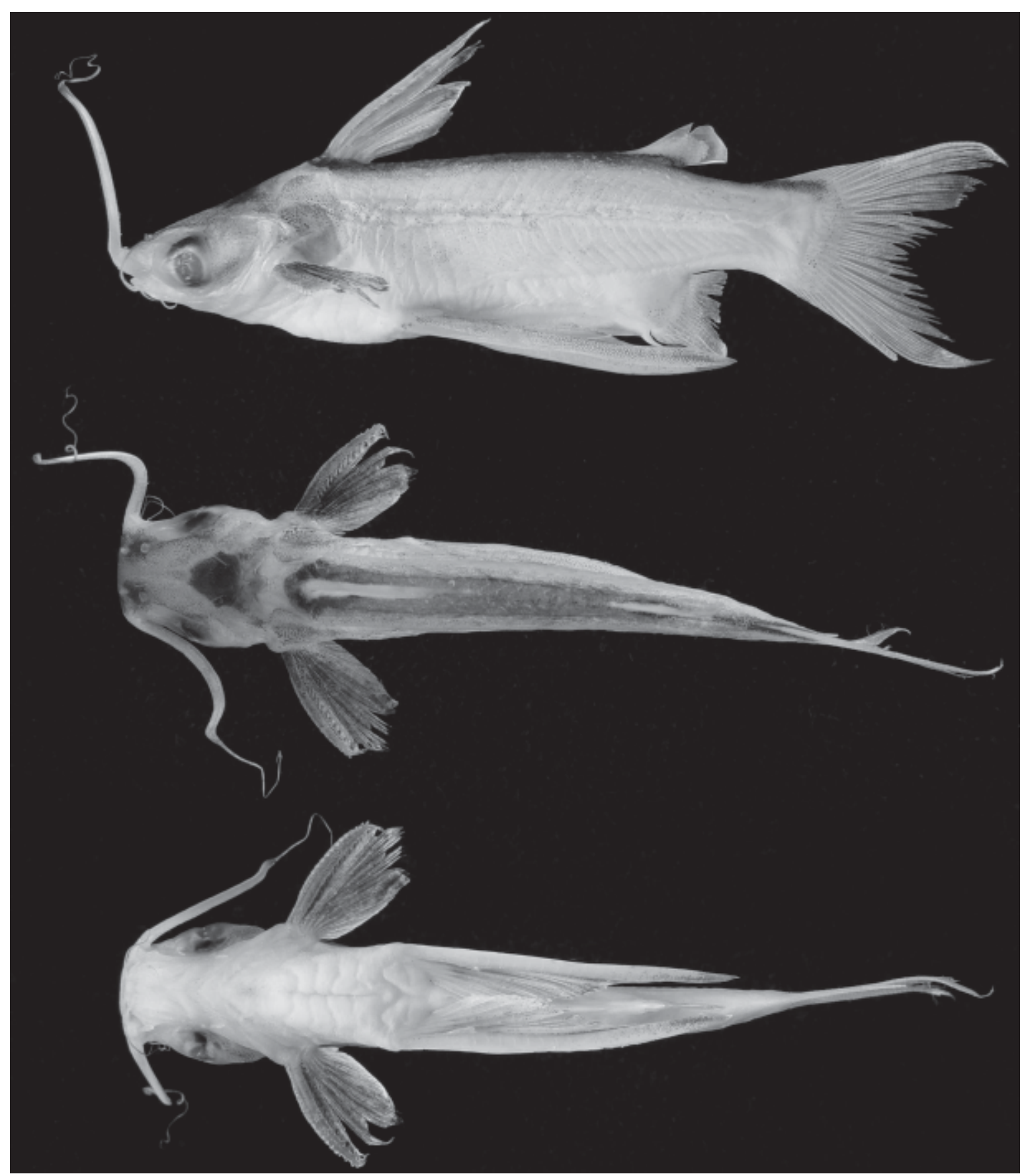

Fig. 1. Entomocorus melaphareus, holotype, MZUSP 76413, 58.6 mm SL.

Pigmentation pattern in alcohol. Ground coloration of head and body white. Middorsal line with wide black stripe extending from dorsal-fin origin to base of hypural plate. Lateral and ventral surfaces of body with fine scattered dark pigmentation of variable intensity but more concentrated on dorsal portion of body. Dorsal surface of head with large middorsal black spot extending from posterior limit of cranial fontanel to base of supraoccipital spine. Dorsal surface of snout with dark ovoid spot extending between anterior and posterior nares. Dorsal and lateral surfaces of head with scattered dark chromatophores, especially postorbitally. Dorsal fin with dark pigmentation along interradial membrane between spine and first branched ray and along distal part of anterior one-half of fin margin; remainder of fin pale. Adipose fin with some scattered pigmentation along base. Caudal fin with indistinct band of dark pigmentation at base, pigment somewhat more concentrated dorsally and with diffuse concentration of chromatophores on distal portion of dorsal lobe of fin. Anal fin with few scattered chromatophores at base, extending onto fin anteriorly. Pelvic fin with concen- 


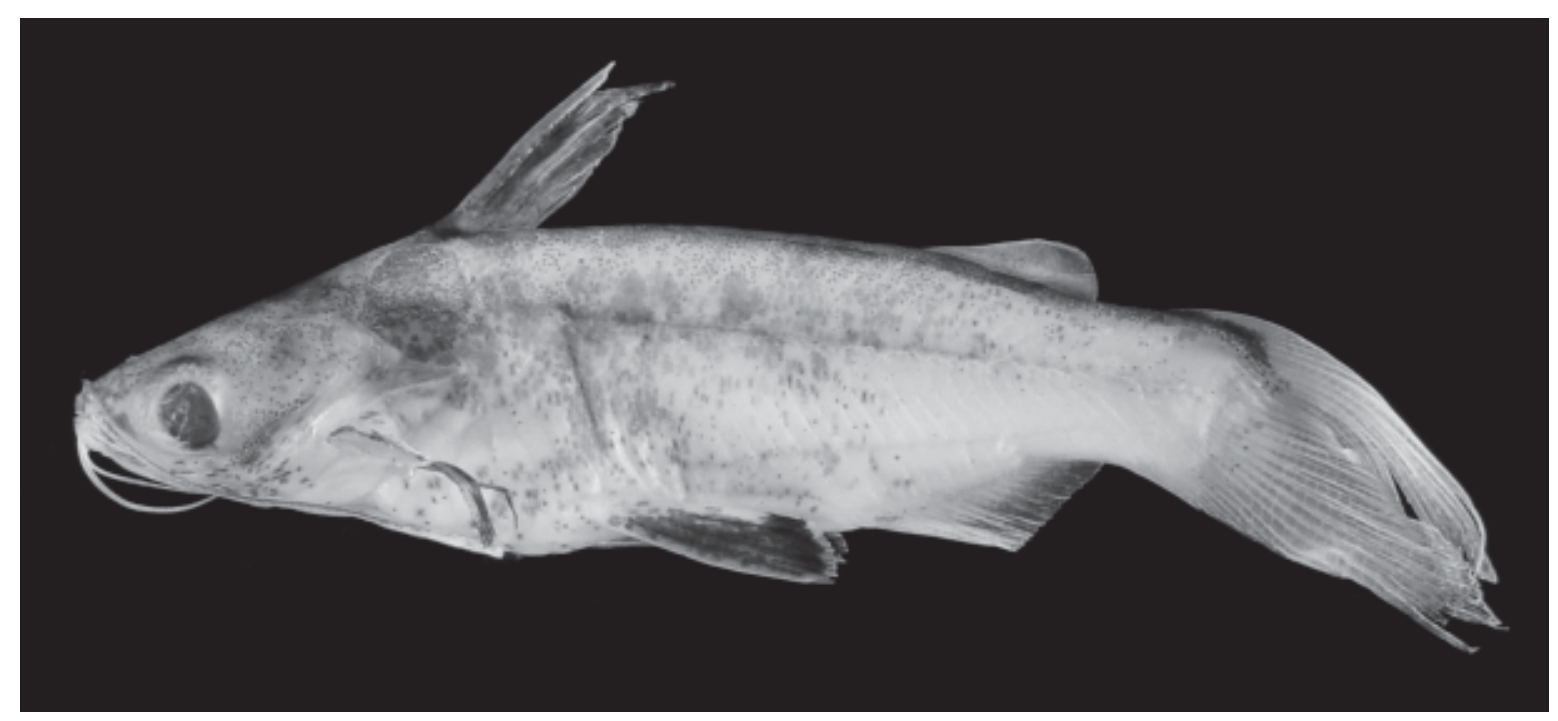

Fig. 2. Entomocorus melaphareus, paratype, MZUSP 76445, 43.1 mm SL.

trated dark pigment on most of interradial membranes. Unbranched fin ray with little pigmentation, appearing pale in contrast to remainder of fin. Pectoral fin with dark pigmentation on all but posterior most portion of fin; pigmentation somewhat more concentrated basally. Barbels with scattered dark pigmentation, appearing pale or dusky.

Color in live specimens. The pigmentation pattern described above was observed in the living specimens, however, when alive, the specimens exhibited yellow pigmentation on the dorsal and adipose fins and the dorsal lobe of the caudal fin.

Sexual dimorphism. The holotype of Entomocorus melaphareus is presumed to be a nuptial male, based on its similarity in appearance to nuptial males of Entomocorus gameroi (called terminal dimorphic male by Mago-Leccia, 1983, pers. obs.). The paratype is a juvenile or a nonbreeding male in which the maxillary barbel is ossified, but not fully developed. Differences between the two specimens are presumed to be sexually dimorphic characters, inasmuch as Mago-Leccia (1983) did not report on any externally evident character that distinguished sexually mature females from non-breeding males or juveniles of either sex. The following description is a summary of characteristics of the nuptial male that are usually not found in non-breeding individuals.

The dorsal-fin spine is proportionally more elongate and slender. The adpressed fin extends to past the origin of the adipose fin, rather than falling far short of the adipose-fin origin. The dorsal-fin spine has few weak serrations on the distal half of its anterior margin, and small rounded unculi. The first ray of the pelvic fin is greatly elongated compared with that of the paratype, extending to level of the caudalpeduncle origin. The ray is expanded into a flattened paddle, with the dorsal surface of the paddle densely covered with small, rounded, spiny, anteriorly directed unculi.

The maxillary barbel is enlarged and rigid for its basal one-half, from the expanded ossification of the maxilla. The ossified portion of the barbel is arched and fits into a shallow groove that extends across the ventral margin of the orbit. The dorsal and medial surfaces of the ossified portion of the barbel are covered with unculi. A row of overlaping, scalelike unculi extends from the distal extent of the ossified barbel to near the base, a character previously mentioned by Ferraris \& Vari (1999). The unculi are small and rounded basally as well as along the medial margin of the barbel.

The snout appears to be broader and somewhat depressed; its appearance apparently due to the enlarged size of the maxilla at the anterolateral margin of the snout. The dorsal surface of the snout is covered with small, rounded unculi, which are larger and denser anteriorly, and extend posteriorly to the nuchal plates.

The anterior serrations of the pectoral-fin spine are curved ventrally, extending well below the horizontal plane of the spine and its posterior serrations. In the non-breeding specimen, all serrations extend anteriorly or posteriorly from the shaft of the spine, but are not curved ventrally. The pectoral-fin spine has clumps of small, rounded unculi on its ventral surface but no unculi were found on the dorsal surface of the spine or on other parts of the pectoral-fin.

The anal-fin is highly modified when compared with the fin of the non-breeding specimen. The base of the three unbranched rays and the three anterior most branched rays are elongated and anteroposteriorly expanded. The distal parts of the expanded rays are either in contact with the more anterior or posterior rays, or nearly so, such that the distal part of the anterior extent of the fin is a rigid, blunty rounded paddle-like structure. The anterior unbranched anal-fin rays that do not contribute to the paddle-like structure are enlarged, but not noticeably elongated. The urogenital opening is at 
the tip of an elongated, flexible urogenital papilla that originates just anteriorly of the anal-fin origin.

Dermal unculi on this species have a pattern unique among auchenipterids. The presence of dermal unculi on the pectoral, pelvic and dorsal-fin rays is recorded for the first time in auchenipterids. Dermal unculi are also present on the dorsal surface of the cranium, a characteristic of several auchenipterid genera, including Auchenipterus, Parauchenipterus, Epapterus, and Pseudepapterus, although not previously described in any detail. A unique characteristic of Entomocorus is the presence of abdominal unculi, distributed in a "V" like pattern and extends from posterior of isthmus and divides into two lateral branches that flank the abdominal region laterally. We first observed this in the holotype of $E$. melaphareus and, although Mago-Leccia (1983) did not mention the presence of these unculi in his specimens of Entomocorus gameroi, we confirm their presence in the nuptial males examined during this study. It is worth mention that no nuptial males of E. bejamini were found in the examined collections during our comparative study.

Distribution. Known only from two localities on the left bank of the Amazon River below Manaus (Fig. 3).

Remarks. This species is quite similar in appearance to its two congeners, Entomocorus benjamini and E. gameroi. Meristically, the three species are not distinguishable and are most readily diagnosed on color pattern differences. There were no obvious morphometric differences that could be demonstrated with the limited sample size of the new species.

The new species is more similar in coloration to Entomocorus benjamini than it is to E. gameroi. Entomocorus melaphaereus and E. benjamini share similar marking on the caudal fin, in which the upper lobe has an indistinct blotch of dark pigment and the caudal-fin base has a diffuse vertical bar. In contrast, E. gameroi has a broad, nearly horizontal stripe of dark pigmentation that extends from the base to the

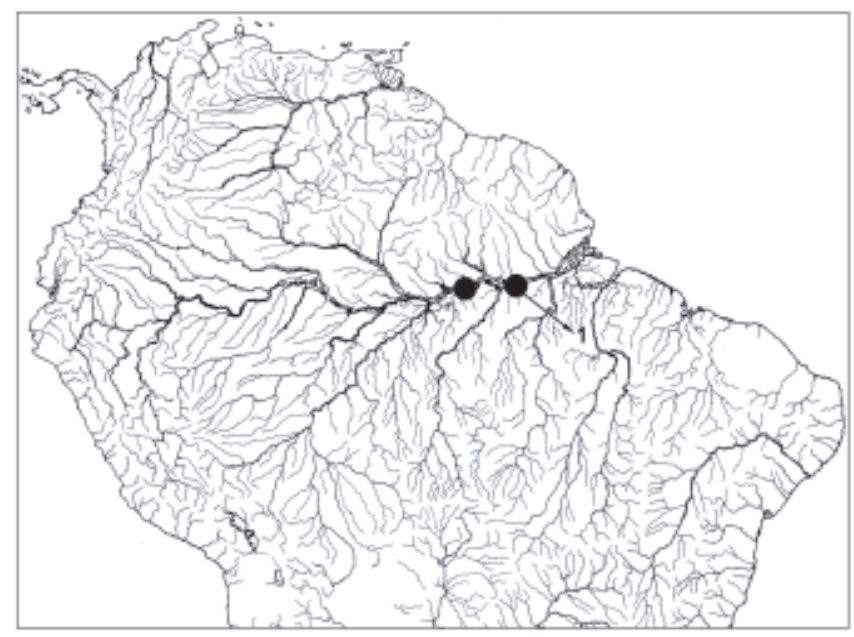

Fig 3. Distribution of Entomocorus melaphareus. Type locality is indicated by the number 1 .
Table 1. Proportional measurements for the holotype and paratype of Entomocorus melaphareus.

\begin{tabular}{lcc}
\hline & Holotype & Paratype \\
\hline Standard length (mm) & 58.6 & 43.1 \\
Percents of standard length & & \\
Head length & 24.4 & 25.9 \\
Body depth & 24.1 & 25.9 \\
Body width & 20.5 & 21.9 \\
Predorsal length & 31.3 & 34.2 \\
Prepectoral length & 26.7 & 27.6 \\
Pectoral spine length & 19.2 & 22.6 \\
Dorsal spine length & 29.1 & 20.0 \\
First pelvic-fin ray length & 46.7 & 20.7 \\
Caudal peduncle height & 11.9 & 13.1 \\
Caudal peduncle length & 19.2 & 18.6 \\
Adipose fin base length & 8.5 & 7.7 \\
Adipose fin height & 6.7 & 6.0 \\
Anal fin base length & 7.8 & 15.4 \\
Percents of head length & & \\
Horizontal eye diameter & 37.8 & 38.4 \\
Snout length & 45.9 & 41.9 \\
Bony interorbital width & 45.5 & 44.4 \\
\hline
\end{tabular}

tip of the upper lobe of the caudal fin. In addition, the lateral surfaces of the body of E. melaphaereus and E. benjamini has little, if any dark pigmentation, whereas E. gameroi sometimes has irregular blotches of dark pigmentation and, often a dark midlateral stripe. However, despite the similarity in appearance of E. melaphaereus and E. benjamini, even darkly pigmented specimens of $E$. benjamini lack the black pigmentation on the pectoral and pelvic fins that characterize the new species.

Etymology. The name melaphareus is derived from the Greek melanos, black, and aphareus, pelvic fin of a tuna, in reference to the unique condition in this species, in which the pelvic fin is dark.

Comparative material. Entomocorus gameroi. Venezuela: Apure: USNM 258187,1, 47 mm SL, not transformed, side channel of río Apure, ca. $5 \mathrm{~km}$ west of San Fernando de Apure, 753’N 67²9’W; USNM 258189, 1, 38 mm SL, not transformed, caño $1 \mathrm{~km}$ south of ferry crossing on río Apurito, where crossed by road from San Fernando to Cunaviche, $7^{\circ} 33^{\prime} \mathrm{N}$ 67³8'W; USNM 258229, 11, 33-45 mm SL, none transformed, río El Cañito where crossed by road from San Fernando to Cunaviche, $7^{\circ} 28^{\prime} \mathrm{N} 67^{\circ} 39^{\prime} \mathrm{W}$; Anzoategui: ANSP 166520, 3 / 36, 57-59 mm SL, transforming males, río Orinoco basin, Soledad, L.Terecaya, 8¹1'30"N 6327'20"W; Bolivar: ANSP 178475 , 1, fully transformed male, río Cunaviche, ca. $20 \mathrm{~km}$ SW of Cunaviche on San Fernando de Apure to Puerto Paez Hwy, 7²0'00"N 67³5'00"W; Guarico: ANSP 158849, 2, 51-58 $\mathrm{mm}$ SL, fully transformed males, Presiamos lagoons between La Antena y caño Falcon. USNM 258192, 3, 38-41 mm SL, none transformed, caño Falcon, río Portuguesa drainage basin, $8^{\circ} 14^{\prime} \mathrm{N} 67^{\circ} 35^{\prime} \mathrm{W}$; USNM 258225, 7, 38-43 mm SL, none 
tranformed, caño to west of highway from Calobozo to San Fernando, about $35 \mathrm{~km}$ south of Fundo Masaguaral (caño Falcon), 814'N 67³5’W; Portuguesa: USNM 348676, 19, 32$44 \mathrm{~mm}$ SL, none transformed, Guanare-Guanarito road at road $\mathrm{km} 60,8^{\circ} 49^{\prime} 39^{\prime \prime} \mathrm{N} 69^{\circ} 20^{\prime} 42^{\prime \prime W}$. Entomocorus benjamini. Bolivia: Dept. Beni, Ballivia Prov., USNM 305608, 3, 45-53 mm SL, none transformed, río Curiraba, $10 \mathrm{~km}$ NE El Porvenir Biol. Sta., 40 Air km E San Borja, $14^{\circ} 05^{\prime} \mathrm{S} 66^{\circ} 17^{\prime} \mathrm{W}$. Entomocorus sp. Brazil: Mato Grosso do Sul: MZUSP 59465, 24, 32-46 mm SL, none transformed, Corumbá, left bank of rio Vermelho, 19037'22'’S 56 57'27'W; MZUSP 59649, 7, 30-52 mm SL, none transformed, Aquidauana, rio Taboco (swamp), 204'12"S $55^{\circ} 38^{\prime} 37^{\prime \prime} \mathrm{W}$.

\section{Acknowledgments}

Field work that resulted in the capture of these specimens was conducted by AA during the "Primeira Expedição Técnico Científica ao Amazonas" sponsored by IBAMA-CEPNOR. Examination of the specimens of this new species was undertaken during a visit by CJF to MZUSP that was funded by a grant from the Neotropical Lowland Research Program of the Smithsonian Institution to R. Vari. R. Reis provided us with photographs of other species of Entomocorus that were being studied by him. M. Sabaj allowed us to examine comparative material at ANSP in his care. An early version of this manuscript was reviewed by R. Reis and R. Vari. The support of these people and organizations is gratefully acknowledged here.

\section{Literature Cited}

Eigenmann, C. H. 1917. New and rare species of South American Siluridae in the Carnegie Museum. Annals of the Carnegie Museum, 11:389-404, pls. 39-41.

Ferraris, C. J. \& R. P. Vari. 1999. The South American catfish genus Auchenipterus Valenciennes, 1840 (Ostariophysi: Siluriformes: Auchenipteridae): monophyly and relationships, with a revisionary study. Zoological Journal of the Linnean Society, 126:387-450, 26 figs.

Lundberg, J. G. \& J. N. Baskin. 1969. The caudal skeleton of the catfishes, Order Siluriformes. American Museum Novitates, 2398: 1-49.

Mago-Leccia, F. 1983. Entomocorus gameroi, una nueva especie de bagre auquenipterideo (Teleostei, Siluriformes) de Venezuela, incluyendo la descripcion de su dimorfismo sexual secundario. Acta Biologica Venezuelica, 11:215-236.

Royero, R. 1999. Studies on the systematics and phylogeny of the catfish family Auchenipteridae (Teleostei: Siluriformes). Unpublished Ph.D. Dissertation, University of Bristol, U.K., 377 p.
Received August 9, 2003 Accepted October 22, 2003 